\title{
Existentialism, Ontology, and Mysticism in Clarice Lispector's \\ A descoberta do mundo
}

LUIZA LOBO

Universidade Federal do Rio de Janeiro

\begin{abstract}
This article aims to place Clarice Lispector as the inventor of a new type of newspaper chronicle. The style of her 468 chronicles published weekly in Jornal do Brasil, from 1967 to 1973, and collected in the book A descoberta do mundo (1984), differs from that of her contemporary male chroniclers, such as Rubem Braga, Paulo Mendes Campos, Fernando Sabino, and Otto Lara Resende, or even women chroniclers, such as Rachel de Queiroz and Dinah Silveira de Queiroz. Mingling Sartre's existentialism and Heidegger's phenomenology with the Jewish mysticism learned as a child enabled Lispector to write in a style that pioneered modern women's prose fiction in Brazil after 1970. This article argues that fragmentation and hybridization are the marks of her "discovery" of a new world as a woman writer, making her crônicas predecessors of today's women's blogs.
\end{abstract}

Keywords: Phenomenology, spirituality, chronicles, philosophy, Jean-Paul Sartre

This article examines the chronicles Clarice Lispector published in the newspaper Jornal do Brasil between the years 1967 and 1973. After Lispector's death in 1977, her son Paulo Gurgel Valente collected her Jornal do Brasil chronicles and published them together in a volume titled $A$ descoberta do 
mundo. ${ }^{1}$ My aim is to establish how existentialism and phenomenology were for Lispector a form of questioning life rather than a theoretical reading on her part. The idea of existence and of being was, for her writing, a kind of mystical search for God and the divine in nature. It did not correspond to Judaism or Christianity, but rather to a hybridization of both religions, mingled with mysticism and her own poetic perceptions of everyday life. Her constant pursuit of meaning resulted in an unceasing and refined search for words in her chronicles. Therefore, they stand as a personal journal written from a subjective viewpoint. They express her literary view of the world rather than a denotative description of everyday external events, as was usual for this genre during this period, especially among male authors. She employs metaphor, stream of consciousness and first-person narration to stress feminism.

In her generation in Rio de Janeiro, there were several important chronicle writers, such as Carlos Drummond de Andrade, and Lispector's friends Paulo Mendes Campos, Fernando Sabino ${ }^{2}$, Otto Lara Resende, Rubem Braga and Stanislaw Ponte Preta (pen name for Sérgio Porto). ${ }^{3}$ Among the women writers, Rachel de Queiroz and Dinah Silveira de Queiroz were very prolific (if unpretentious and realistic), and before them, Cecília Meireles.

Lispector worked as a professional reporter and editor of the newspaper $A$ Noite in 1942. Nonetheless, she wrote most of her chronicles not as a journalist but as a fiction writer (see "Amor imorredouro," Sept. 9, 1967, 20). A descoberta do mundo is a collection of the chronicles she published as a freelancer in the prestigious Caderno B, the cultural supplement of Jornal do Brasil, from August 19, 1967 to December 29, 1973. There is a total of 446 of these chronicles: 35 written in 1967, 122 in 1968, 84 in 1969, 70 in 1970, 56 in 1971, 61 in 1972 and 38 in 1973 (leaving out 50 others without explanation). Her dismissal from the

\footnotetext{
${ }^{1}$ Quotations refer to the 1984 edition. Although the new edition by Rocco is titled Todas as crônicas (2018) and presents about 50 new chronicles from Jornal do Brasil, it suppresses 30 literary ones that Lispector also published as short stories. These are published in Todos os contos (2018) to avoid repetition. This new volume places the dates only at the end, which is not convenient for chronicles.

${ }^{2}$ As a publisher, Fernando Sabino placed her stories and novels in Sabiá (former Editora do Autor), a publishing house he owned with Rubem Braga and Walter Acosta. While she lived abroad, he helped her find other publishers for her work.

${ }^{3}$ Lispector wrote on Sérgio Porto's death, in "As dores da sobrevivência: Sergio Porto": "Oh, Deus, por que não eu, em lugar dele? [...] Perdoe eu ter sobrevivido. Estou muito cansada" (A descoberta do mundo, 28 Sept. 1968, 201-02). She sounded depressed, as she was often, this time for not having called him up.
} 
paper took place at the same time that other Jewish employees were dismissed, as anti-Semite General Geisel looked to assume the presidency of Brazil. As Moser (322-26) and Gaspari (49-50) point out, this was likely a failed attempt on the part of the newspaper to please the new president and escape its own imminent bankruptcy.

\section{Lispector's Chronicles Innovative Style}

Lispector brought innovation to the genre of chronicle writing by leaving out the traditional description of events in a precise place and time and privileging the chronicle as an experimental piece of poetic art. She also tinted her almost confessional style with a philosophical tone. In this her chronicles differ from this usually matter-of-fact and realistic genre. She most often focused on events related to her own everyday life and thoughts, instead of political or social facts, as is often the case.

Lispector felt deeply connected to children, her home and family. She often referred affectionately to animals, including pets, such as her two dogs or her son's rabbit. She was obsessed with chickens, and makes them her protagonists, as in "Um pintinho" (Feb. 10, 1968, 91-92) and "Atualidade do ovo e da galinha" (July 5, 12, 19, 1969, 313, 318, 322-24), ${ }^{4}$ and in the literary chronicles "A princesa (noveleta)" (Aug. 3, 9, 16, 23, 30, 1968, 328-46) and "Travessuras de uma menina (noveleta)" (Jan. 3, 10, 17, 24, Feb. 7, 1970, 393-410). ${ }^{5}$ In "Nos primeiros começos de Brasília" (June 20, 1970, 452-56), she employs Surrealist imagery to refer to the new modernist capital of Brazil, que "foi construída sem lugar para ratos. Toda uma parte nossa, a pior, exatamente a que tem horror de ratos, essa parte não tem lugar em Brasília" (453), ${ }^{6}$ and adds: "Fazem tanta falta cavalos brancos soltos em Brasília" (456).

Lispector constantly appeals to God, to metaphor and to poetic prose, so that she is rarely realistic in her style. She often asks: "O que está morrendo, meu Deus?-Não chorei nenhuma vez em Brasília. Não tinha lugar.-É uma praia

\footnotetext{
${ }^{4}$ This chronicle is a reprint of her short story "O ovo e a galinha" (A legião estrangeira, 1964).

${ }^{5}$ See "Bichos I-II" (13 March 1971, 517-24), in which she comments on rabbits, owls, turtles, and especially Dilermando, the dog she found in Naples and later had to abandon to move to Bern, Switzerland, due to her husband's new diplomatic post (524).

6 "Brasília de ontem e de hoje" (Oct. 7, 1972, 678-83) is another chronicle on the new capital.
} 
sem mar.-Em Brasília não há por onde entrar, nem há por onde sair” (June 20, 1970, 454). She employs oxymorons and aporias to express her perplexity before Brasília's fantastic tall buildings in the emptiness: "Vou embora para os meus outros crimes, os que Deus e eu compreendemos. Mas sei que voltarei. Sou atraída aqui pelo que me assusta em mim.-Nunca vi nada igual no mundo. Mas reconheço esta cidade no mais fundo de meu sonho [...] é uma lucidez" (454); "Só Deus sabe o que acontecerá com Brasília" (455). And she concludes once again with a Surrealist metaphor: "A beleza de Brasília são as suas estátuas invisíveis" (456).

Another trait of her originality is to make her typewriter into the main topic of several of her chronicles, as in "Primavera ao correr da máquina" (Sept. 23, 1967, 27-29), "Insônia infeliz e feliz" (Sept. 23, 1967, 81-82) and "Ao correr da máquina" (April 17, 1971, 529-32). In "Gratidão à máquina" (20 January 1968, 82-83), she states that she always writes with her portable Olympia on her lap. In "Até a máquina?" (Feb. 5, 1972, 636-38), she is surprised to realize that the divine is always present, when the person who fixes her typewriter wrote "Que Deus seja louvado" on a sheet of paper to test it. As one can see in "A máquina está crescendo," she fears that mechanization will dehumanize humankind, and she resorts to religion and to God:

A máquina está crescendo. Está enorme. A ponto de que talvez o homem deixe de ser uma organização humana. E como perfeição de ser criado, só existirá a máquina. Deus criou um problema para si próprio. Ele terminará destruindo a máquina e recomeçando pela ignorância do homem diante da maçã. Ou o homem será um triste antepassado da máquina; melhor o mistério do Paraíso. (4 March 1970, 420)

In her innovative, modernist style, Lispector resorts to metafiction, a technique typical of theoretical texts, when she includes in her chronicles answers to criticism that she received on her writing, and introduces a second voice to

\footnotetext{
${ }^{7}$ In "Propaganda de graça" (Dec. 15, 1973, 763-64), she mentions her Olympia, then her Olivetti, and other typewriters as if they were family, and praises her Underwood: "Essa máquina eu amei mesmo: ela durou tanto que aguentou eu escrever sete livros" (764), and concludes: "Máquinas, qualquer uma, são um mistério para mim. Respeito-lhes o mistério" (764).
} 
question herself: "Hermética?" (Feb. 24, 1968, 98), "Ser cronista" (June 22, 1968, 155-56), “Como é que se escreve?” (Nov. 30, 1968, 229-30), "Ficção ou não" (Feb. 14, 1970, 412-13), "Escrever ao sabor da pena" (March 14, 1970, 425), "Lembrança da feitura de um romance" (May 2, 1970, 437-38), "Escrever" (May 2, 1970, 439), "Poesia” (Oct. 10, 1970, 491), "Máquina escrevendo" (May 29, 1971, 542-44), "De natura florum, Dicionário" (April 3, 1971, 525-28) and "Forma e conteúdo" (Dec. 20, 1969, 390).

Metafiction even develops into an existential mode of self-questioning in "Sobre escrever": "Às vezes tenho a impressão de que escrevo por simples curiosidade intensa. É que, ao escrever, eu me dou as mais inesperadas surpresas. É na hora de escrever que muitas vezes fico consciente de coisas, das quais, sendo inconsciente, eu antes não sabia que sabia" (Dec. 20, 1969, 390). By choosing an impressionistic point of view to approach intimate facts of everyday life, Lispector's style shares a certain affinity with Katherine Mansfield's own use of stream of consciousness. ${ }^{8}$ In these short tects, Lispector employs epiphany to express the surprise she feels at discovering or reinventing the world through language. Some of her chronicles are in fact explicitly famed as short stories still "in progress," or "noveletas." This allows her to bring together God, mysticism, and her more domestic sensations. ${ }^{10}$ Lispector's style becomes in this way meaningfully experimental, both with respect to her fiction and her many chronicles, which were, in more than a few cases, essentially short stories "in progress."

A good portion of Lispector's chronicles in A descoberta do mundo have a direct link to the interviews she conducted with important cultural figures or famous writers of her time for the magazines Fatos e Fotos/Gente, Bula, and

\footnotetext{
${ }^{8}$ Lispector states that she discovered a book by Mansfield in a bookstore when she was 15 (Feb. 1973, 721-23), although it probably happened when she was 20 . The fact that she always deducts five years from her real age is probably due to her fear of being expatriated, since she was a Russian Jew until she reached the age of 23, when she acquired Brazilian citizenship. The first exhibition showing her identity documents was held at Centro Cultural Banco do Brasil in Rio de Janeiro on August 29, 2008, and her manuscripts are now kept at Arquivo-Museu de Literatura Brasileira at Fundação Casa de Rui Barbosa in that city.

${ }^{9}$ Souza presents a complete study of alterations, revisions and reprints of the literary chronicles that also appeared in her books. These were not included in Todas as crônicas (2018).

${ }^{10}$ For more on epiphany, see Olga de Sá; Romano de Sant'Anna; and Lobo (“Clarice Lispector e Virgínia Woolf”).
} 
Manchete. ${ }^{11}$ She was always original, as when she switches positions between interviewer and interviewee, in "A entrevista alegre" (Dec. 30, 1967, 68-72). Among other instances, a young woman named Cristina visits the writer to interview her, and Lispector soon changes position and begins to interview the girl (70). She states an aporia, "Escrever é um dos modos de fracassar" (71), but when the girl asks her why, she is unable to explain. The chronicle ends, however, in a lighter tone: "depois que li a entrevista, saí tão vulgar. Não me parece que eu seja vulgar. E nem tenho olhos azuis" (72).

\section{Feminism in Lispector's Chronicles}

Like many women authors of her generation, Lispector worked with subjects that were considered "merely feminine." However, she was able to make them into literary and interesting topics, by shifting description of the world of action to her own psychological state of mind, related to dealing with her children, her maids, her home, her dog, or the trifles of everyday life.

Rather than realistic description, she employs metaphor or hidden meaning to rephrase "feminine" topics, such as flowers, as in "Jasmim" (April 7, 1973, 733): "Mas falei em perfume. Lembrei-me do jasmim. Jasmim é de noite. E me mata lentamente" (733). Still other chronicles deal with these "feminine" topics that she makes meaningful, as in "Rosas silvestres" (May 25, 1968, 142-43), "Os perfumes da terra” (Sept. 7, 1968, 188) and De natura florum, Dicionário (April $3,1971,525-28) .{ }^{12}$ She also revalues beauty and nature, themes which are often related to the "feminine," but in a derogatory way.

Before a 1966 fire in her bedroom, Lispector was an extremely beautiful and successful woman. She bore an air of elegance in the somewhat exotic and old-

\footnotetext{
${ }^{11}$ For cultural figures, see: "Chico Buarque de Holanda" (Feb. 4, 1968, 88-89; Feb. 10, 1968, 92); "Oi, Chico!” (March 23, 1968, 109-10); "Xico Buark me visita” (June 26, 1971, 556-58); "Tom Jobim" (July 3, 10, 17, 1971, 559-68) and "Trajetória de uma vocação" (Sept. 29, 1973, 752-54). The latter piece is on the conductor Isaac Karabtchevsky, who shocked the audience at the Municipal Theater by playing Buarque's popular music in a classical concert (754). For writers, see: "Entrevista-relâmpago de Pablo Neruda" (April 12, 19, 1969, 273-78); "Alceu Amoroso Lima" (Feb. 8, 15, 22, 1969, 255-63), a well-known Christian thinker of her time; "San Tiago" (Jan. 6, 1968, 75-77), on the diplomat and politician San Tiago Dantas; and "Desculpem, mas não sou profundo" (Dec. 16, 1972, 703-05), on Érico Veríssimo.

${ }^{12}$ Lispector wrote newspaper columns on "feminine" topics to survive, under the pen name of Helen Palmer and Teresa Quadros. Between 1959 and 1962, she wrote a column for adults called "Children's Corner" for the magazine Senhor.
} 
fashioned clothes she had brought from Europe. The cause of the fire was simple if tragic: Lispector had been smoking in bed after taking sleeping pills. The fire left her with physical as well as psychological scars. Her face, body and right hand were severely burned, and she spent several days in the hospital hovering between life and death, and her hospital rehabilitation took months. The accident divided her life into two phases. After it, she felt like a lonely woman separated from her husband and living in a Catholic country where divorce was unlawful. She felt she carried too many financial and familial problems on her shoulders, especially the schizophrenia from which her older son, Pedro, suffered. Subsequently, Lispector lived in a constant state of melancholia. ${ }^{13}$ She complained of mental and physical exhaustion, a condition that today would almost certainly be diagnosed as manic depression. Above all, the traumatic events of her life (see "Santiago," Jan. 6, 1968, 75-77) culminated with the longlasting illness and death of Lúcio Cardoso, her best and most beloved friend (Jan. $11,1969,243-45) .{ }^{14}$ She projects her own morbid feelings onto an animal, in "Morte de uma baleia" (Aug. 17, 1968, 177-80), in which a whale gets stuck in the sand on Leblon Beach, and while that "montanha de inocência" (180) is still alive, some poor people cut into its flesh to take it home and eat it (180). This sad event condenses her own sense of loss of sensuality and of physical decay (179). However, at the end of this chronicle, she resurrects herself and states: "Porque desistir de nossa animalidade é um sacrifício" (180).

\section{Existentialism, Ontology and Religion for Lispector}

Jean-Paul Sartre and Simone de Beauvoir visited Brazil for two and a half months, from the middle of August until the beginning of November 1960. They received much attention from the press and became well-known to the Brazilian public. Existentialism was commented upon in all the papers. Its fundamental thesis is that existence precedes essence: it is one's acts that prove one's identity,

\footnotetext{
${ }^{13}$ Lispector also translated books to make ends meet. She often complained of feeling tired and lacking a subject in her chronicles (see "O ato gratuito," April 8, 1972 648-50). She constantly turned to God in her loneliness and loss. In "Teosofia" (Dec. 13, 1969, 385-86), a cab driver "me dá uma lição teosófica" (385) and preaches to her about brotherhood. However, she states, "não me senti irmã de ninguém no mundo. Eu estava sozinha" (386).

${ }^{14}$ She also comments on João Guimarães Rosa's death ("Desculpem, mas se morre," May 22, 1971, 539).
} 
contradicting metaphysics. From Plato to the eighteenth century, metaphysicists believed that humans inherit an innate soul, or an essence. For existentialism, on the contrary, life is foremost, and it is one's life and actions that define one's self. Not many Brazilians read Sartre's Being and Nothingness (1943), but his ideas were in the air. In a famous book, O mundo de Clarice (1966), later included as an article in $O$ dorso do tigre (1969), Benedito Nunes links Lispector's writing of A paixão segundo G.H. (1964) to Sartre's novel Nausea (1938).

Derived from Husserl's phenomenology, which stressed that reality exists as a phenomenon only when it is perceived by the human mind, existentialism held that one can interpret reality and choose one's destiny. Life should be built according to one's will, not to some universal or essential truth that precedes and dictates one's existence outwardly. Existentialism questioned conventional truths and supported one's freedom through action in relation to the "other," or "beingfor-itself" (pour soi). This is what distinguishes the latter (pour soi) from a beingin-itself (en soi), which would possess some innate or essential nature that is impossible to grasp.

Many Brazilian intellectuals became existentialists in the 1960s and 1970s, and Sartre's fiction was widely read. Sartre's Existentialism is a Humanism (1946) was a well-read book that defended this philosophy against the accusation of its being atheistic and nihilistic. Lispector blended these trends with Christian thought, then in fashion, as in Alceu Amoroso Lima (whom she interviews), Teillard Chardin, Paul Claudel, and Murilo Mendes. ${ }^{15}$

Sartre's study Anti-Semite and Jew (1948) focused on the idea of "bad faith," or self-deception, which he considered a moral defect. It consists of the intentional representation of oneself feigning being somebody else in order to hide some reproachable inner truth (being-in-itself, en soi) that is not good to expose in the apparent being-for-itself (pour soi). Fighting solipsism, or concentration on her own mind, Lispector became increasingly aware of the importance of questioning the meaning of the world. She wrote several passages about dropping one's mask and facing life and death in order to reveal one's true self. She was obsessed with the idea that people hide their consciousness by

15 Her division between Christianity and existentialism explains why she reacts in shock when she interviews José Carlos de Oliveira and he declares almost cynically his disbelief in any truth and that he is an "existentialist" who lives day by day ("Quase briga entre amigos," Jan. 17, 1973, 71214). 
wearing a social mask, and referred to the masks that actors wear in the Asian theatre or to the scars that a mask might hide, as in her short story, "A bela e a fera ou a ferida grande demais" (1977). This obsession led her to dedicate a long chronicle, titled "Persona" (March 2, 1968, 99-102), to Bergman's film, in which she confesses that she also wears a mask. Revealing an existentialist choice, she states: "Escolher a própria máscara é o primeiro gesto voluntário humano" (100). And she adds that a person, after years of wearing a social mask, may see it fall and his face become rigid, crest-like, and then he dies. The only way out of this suffering is resurrection, as in Christianity: "Como pessoa teve que passar pelo caminho de Cristo" (101). Now here, instead of keeping to Existentialism, she turns to religion, mysticism or the supernatural.

Lispector often contemplates the idea of God, despite showing metaphysical doubts. In "Medo da eternidade" (June 6, 1970, 446-48), the author reduces the idea of eternity for her as a girl to her fear of dying by chewing a gum that would never end. Her chronicle "Sou uma pergunta" (Aug. 14, 1971, 575-78) launches a series of metaphysical questions that she does not answer because they are unanswerable. She thus resorts to concrete, existentialist imagery to deconstruct metaphysics about the world, religion, clichés or certain beliefs: "Quem fez a primeira pergunta? Quem fez o mundo? Se foi Deus, quem fez Deus?" .. "Quem fez a primeira cadeira? Por que se lava roupa?" (575) "Por que há a raiz quadrada? Por que há flores?" (576). The chronicle ends inconclusively, with the question "Por quê?" (578) left in suspense.

"Descoberta" (Feb. 21, 1970, 414-15) also points to apparent truths in everyday reality that one takes for granted, but which can be questioned through existentialism and phenomenology. A man sees a woman in the street and smiles: "Ele sorriu porque ela não sabia que ele sabia que, assim como um cachorro é um cachorro, aquela mulher era aquela mulher" (415). Thus, although the ontological problem of being remains, it is reduced to existence, to the consciousness about life, or "being there," Heidegger's Da-sein. Once again, she denies metaphysics and reduces it to simple everyday meals in "Comer, comer" (Nov. 16, 1968, 222-23), when she describes her home as non-metaphysical: "O fato é simplesmente que nós gostamos de comer. E sou com orgulho a mãe da casa de comidas. Além de comer, conversamos muito sobre o que acontece no Brasil e no mundo, conversamos sobre que roupa é adequada para determinadas ocasiões. Nós somos um lar" (223). More than witty or ironic statements, these 
reductions of metaphysics to concrete life are at the core of Heidegger's inquiry on ontology (Being) and Sartre's existential or phenomenological approach to philosophy.

Lispector lived 16 years in Italy, Switzerland and England, a period when she was able to read at ease. She certainly read Heidegger's Introduction to Metaphysics, as well as his very poetic Off the Beaten Track. Heidegger's idea of Da-sein (Being here and now) is present in her novels, short stories and chronicles as a constant experience of "being there." She always expresses the need to focus on the deep consciousness of one's being, opposite to unconscious objects or to people that only lie in the world (being-in-itself) without exerting an existence of their own. In Introduction to Metaphysics, Heidegger mentions that there are "mobs" of people who are not real beings, but mere objects that lie there, and who therefore fall into nothingness. Lispector's approach to language derives from Heidegger's idea of re-velation, or illumination, as in her constant grasp of being and her etymological re-discovery of words.

From her chronicles and other writings we can conclude that Lispector's knowledge of Sartre's existentialism or Heidegger's ontology was far from being deep, but she drew inspiration from their ideas, not only by reading some of their works, but also because they circulated in newspaper articles and were topics of conversation among her intellectual friends.

\section{Mysticism and the Discovery of the Sacred World}

Even though we see traces of existential and ontological thought in Lispector's chronicles and fiction, she repeatedly denied being an intellectual: "Sou feliz de pertencer à literatura brasileira por motivos que nada têm a ver com literatura, pois nem ao menos sou uma literata ou uma intelectual" ("Pertencer," June 15, $1968,151-53,152)$. Later in this chronicle she recalls the sad demands made on her, based on some old Ukrainian legend, such as healing her mother just by being born, in which she failed: "Minha mãe já estava doente, e, por uma superstição bastante espalhada, acreditava-se que ter um filho curava uma mulher de uma doença. Só que não curei minha mãe. E sinto até hoje essa carga de culpa: fizeram-me para uma missão determinada e eu falhei" (153).

She never assumed a Jewish identity, nor did she belong to the Jewish community in Rio. It was a shock to her to be dismissed from Jornal do Brasil 
for being a Jew. In fact, her main inclination remained not with religion, nor with a specific faith, but rather towards a mystic and general idea that permeates Judaism, Catholicism, and ends in astrology and esoterism. She was more mystical than either Jewish or Catholic, although she often refers to the Old Testament, which belongs to both religions. ${ }^{16}$ As Nelson Vieira argues in the newspaper Zero Hora (RS, reprinted in Remate de males, 1989, 207-09), she did not consider herself a Jew in the least, but a Brazilian. She studied in Catholic, Jewish and non-confessional public schools in Recife. Most important is that her childhood upbringing was non-sectarian. ${ }^{17}$

Lispector blended her Jewish upbringing with the Catholic background in which she lived, and some of her chronicles show this religious hybridization. She never mentions Jewish thinkers, but she cites several Catholic ones, such as Georges Bernanos (“Aprendendo a viver," Dec. 28, 1968, 235-37), and Alceu Amoroso Lima (Feb. 8, 15, 22, March 1, 1969, 255-59), whom she interviewed. In "Prece por um padre" (Sept. 16, 1967, 24), she prays for a priest, not the other way around: "Uma noite gaguejei uma prece por um padre que tem medo de morrer e tem vergonha de ter medo" (24); "Padre X... tinha me pedido para rezar por ele" (25). ${ }^{18}$ This chronicle shows how much more adapted to Catholicism Lispector was, in spite of Benjamin Moser's stress on her Jewish origins in his biography of her (2009). In "Por detrás da devoção" (Dec. 2, 1967, 53-58) she again turns to Nossa Senhora da Aparecida, when she is advised by her cook

\footnotetext{
${ }^{16}$ On the same day as in her chronicle "Um fenômeno de parapsicologia" (July 24, 1971, 569-70), she published "Salmo de Davi, n. 4," in Biblical language: "Ouve-me quando eu clamo, ó, Deus da minha justiça" (570).

${ }^{17}$ In keeping with a tendency typical among immigrants to Brazil, Lispector's father, Pinkhas, changed all his family members' names upon arriving in Maceió (AL) in 1922. He, Pinkhas, became Pedro, Mania, their mother, became Maria. The daughters were renamed Elisa, Tania and Clarice (whose original name was Haia and was buried as such in Rio). Lispector's utmost concern was to integrate into Brazilian society and into the Portuguese language for fear of being considered a Russian or a Jew and finding herself expatriated, as Olga Benário Prestes was. The latter was a Jew and the wife of the communist leader Luís Carlos Prestes. After being deported by the dictator Getúlio Vargas, the Nazis sent her to the gas chambers. Brazilian citizenship could only be applied for when one came of age, at 21. Lispector even wrote a letter to Vargas, in the hope of speeding up this process, but she only acquired Brazilian citizenship at the age of 23 , by marriage.

${ }^{18}$ In "Um pedido" (Feb. 10, 1968, 90), she advises a person who drinks too much to stop or at least drink less. On the same day, in "Deus" (Feb. 10, 1968, 90), she questions: "Mesmo para os descrentes há a pergunta duvidosa: e depois da morte?" (90). Changing from religion to psychology, she asks God's help because she is destructive, and then adds: self-destructive (9091).
} 
Jandira to light a candle for the saint, since she had been inadvertently calling another maid, whose name was actually Aninha, by the name Aparecida (54).

The chronicle "As grandes punições" (Nov. 4, 1967, 39-41) contains the Catholic idea of punishment, which derives from Judaism. Lispector confesses that she and Leopoldo, her best friend in school and a Jewish boy, behaved very badly in class. She then begins to fear punishment, which never comes, but she cries with fear all the same. Her chronicles "Das doçuras de Deus" (Dec. 16, 1967, 60-62), "De outras doçuras de Deus" (idem, 63), "As caridades odiosas" (Dec. 6, 1969, 381-384) and "Teosofia" (Dec. 13, 1969, p. 385-386) deal with the theme of charity, common to both religions. The latter tells of a mother who lives in the street with her three children. Many other texts move between the two faiths in a hybridized manner, as is usual in Brazilian culture, as in "Perdoando Deus" (Sept. 19, 1970, 484), "Salmo de David, no 4" (24 July 1971, 570), "Dies irae" (Sept. 25, 1971, 593) and "Hoje nasce um menino" (Dec. 24 1971, 620).

Lispector's knowledge of Judaism almost certainly came from her father, who had studied the Talmud, and from the year she spent in a Jewish school while the family lived in Recife. She was aware of the religious significance of numbers in the Kabbalah, and as a girl she taught private arithmetic classes. ${ }^{19}$ She was also aware that some Jewish religious secrets could not be shared: "Um homem me disse que no Talmude falam de coisas que a gente não pode contar a muitos, há outras a poucos, e outras a ninguém” (“Ao correr da máquina," April 17, 1971, 529-32, 529).

Lispector's family came from the region of Podolia, in Western Ukraine. This region was the site of hundreds of anti-Jewish pogroms during the turn of the twentieth century, and Lispector's family emigrated in 1921. They went first to Germany before arriving in Maceió, Brazil, when Lispector was only two years old. Prior to the Bolshevik Revolution in Russia and the subsequent rise of Ukranian nationalism, Podolia had been an important center of Jewish culture, and it was the fatherland of two important Jewish mystics, rabbi Baal Shem Tov (born around 1700 in Poland), and rabbi Nachman of Breslov (born in 1772 in

\footnotetext{
${ }^{19}$ The Lurianic Kabbalah, based on the Zorah, was spread by the sixteenth-century rabbi Isaac ben Solomon Luria Ashkenazi. He was born in Jerusalem and died in Syria. He wrote poems in Aramaic and the eight volumes of the famous Tree of Life. Jewish popular faith is full of golems (doubles, phantoms) and dibbuks (devilish spirits of the dead) that inspire the supernatural.
} 
Poland). ${ }^{20}$ The former created the concept of hased which is linked to the Almighty (Adonai). It refers to the same God that was incarnated in Christ, as depicted in the book The Imitation of Christ (1418), a kind of second Catholic Bible widely read in Lispector's time. In A descoberta do mundo, she often refers to Christ's crucifixion, as well as in her novels A paixão segundo G.H. and A viacrucis do corpo (1974). In "Lembrança de um homem que desistiu" (Dec. 18, 1971, 618-19), she states: "O verdadeiro sentido de Cristo seria a imitação de Cristo. Só que o próprio Cristo foi a imitação de Cristo" (619). This aporia is so metaphorical that she can barely be accused of atheism or blasphemy.

The members of the Hasidic sect were known as "the drunkards of God," as they were in a state of mind like that of Muslim Sufis, one of total dedication to the spiritual and magical. This kind of mysticism is present in Jewish didactic and popular tales. ${ }^{21}$ It can be found it Lispector's style, in both her chronicles and fiction, and increasingly so in her life. For example, "Brain Storm" (Nov. 22, 1969, 374-76) contains a kind of repetitive mantra calling for happiness or reparation of the heart, and an eagerness to find God in all earthly things (but not beyond things, as in metaphysics). She mentions God 181 times in A descoberta do mundo. So many mystical references may give her chronicles and writings a certain resemblance to what would be later called self-help books. However, her mixed appeals either to the Christian God, to Jewish or even to Greek values, stand as evidence of her religious hybridization - that many would call assimilation —as in "Como uma corça" (Jan. 27, 1968, 84), or calling "o deus," in A paixão segundo G.H.

\footnotetext{
${ }^{20}$ Lispector's family emigrated from a Jewish community near Sawranh (Ukraine) to Maceió (AL) in 1922 and later to Recife. Elisa Lispector's novel No exílio (1948) gives a touching picture of the horrible conditions of their escape from Ukraine. Clarice was born on the way, when her mother was already very ill (Moser), suffering from a paralyzing disease. During their childhood, their mother spent her days sitting in a rocking chair by the window, finally dying on Sept. 21, 1930 The remaining family members moved to Rio in 1935. Her father died from a surgery on Aug. 23, 1940. Lispector graduated in Law in 1943, when she became a Brazilian citizen and married the diplomat Maury Gurgel Valente. The couple lived abroad for 16 years. She had two children, Pedro and Paulo. She returned with her children to Rio in 1959 and officially separated from her husband in 1965.

21 "Desencontro" (571) is written as a small fable, comparable to a Hasidic tale: "Eu te dou pão e preferes ouro. Eu te dou ouro, mas tua fome legítima é de pão" (571). Hasidism coincides in great part with Jesus's teachings, for it links spirituality and simplicity with the acceptance of the differences among people and in the world.
} 
Lispector's attachment to everyday trifles may be considered an important tool against the universal metaphysical truths, as exposed in Existentialism, to grasp the meaning of existence in the times of turmoil during which she lived, personally and politically. First, her own fear of being deported to Nazi Germany, later, after 1964, the threat against intellectuals by the military regime. She often asks: “Oh, Deus, e eu que não sei rezar!” (“Que me ensinem,” Feb. 4, 1968, 87) but, although feeling unable to pray, she does it all the time. She concludes this chronicle by complaining: "Oh, Deus, eu já fui muito ferida" (idem, 87). She is a pioneer in her interest in magic, esoterism and fortune telling, explicit in her last book publishedin her lifetime, $A$ hora da estrela (1977).

While Lispector does not commit to any religion, she respects certain religious precepts. For example, in "Ao correr da máquina" (April 17, 1971, 52932), she blames Virginia Woolf for not having gone "until the end" (like her suffering mother?): "Não gosto quando dizem que tenho afinidade com Virginia Woolf (só a li, aliás, depois de escrever o meu primeiro livro): é que não quero perdoar o fato de ela se ter suicidado. O horrível dever é ir até o fim" (529). The condemnation of suicide is of course common to both Christianity and Judaism.

The use of metaphors, aporias and contradiction is so frequent in her imagery style that Lispector disrupts Aristotelian logic and opens her writing to a whole universe of linguistic invention. This kind of apparently contradictory logic was later characterized by Jacques Derrida as logic of the supplementary, or inclusive logic. It is not based on Aristotle's logic of the third exclusive, that is, something can only be affirmed or denied, but on the argument that theories complement or supplement one another, because there is not one definitive truth.

Lispector's increasing melancholia and difficulty with social interactions even in such a lively city as Rio led her to increasingly search for seclusion in her apartment in Leme. She resented being labeled as difficult and eccentric in her relationships, and being criticized as hermetic in style, to the point of having been called a "sacred monster" ("Brain Storm," Nov. 22, 1969, 374-76). At the same time, she became increasingly popular, and her magic, esoteric style became much appreciated by her women readers. She further elaborated on the theme of magic with her strange collection of short stories Onde estivestes de noite (1974), featuring witches and nightmares. To add to her notoriety, she dazzled the audience at a Witchcraft World Conference in Colombia, in 1975, by reading her short story "O ovo e a galinha." 
Her novel A hora da estrela (1977) deals with fortune telling and death prediction, but it resulted from a lasting appreciation of the supernatural on her part, as we read in A descoberta do mundo: "A Vidente" (Nov. 25, 1967. 51), "Descoberta" (Feb. 21, 1970, 414) and "Um fenômeno de parapsicologia" (July $24,1971,569-70)$. In the latter, a woman who is a medium is called to Lispector's apartment, and she writes down a short story that was totally in Lispector's mind, with her exact words, although she had never read her books. In "Análise mediúnica" (Dec. 15, 1973, 762-63), another medium, Maria Augusta, nicknamed Eva, visits Lispector and advises her to hold back her emotions, which the author resists. In "É sobrenatural" (June 28, 1968, 310), she concludes that she does not live "day to day", but "life to life."

By 1973, Lispector increasingly refers to God, magic themes, fortune telling, popular beliefs, religious faith, mysticism, and the supernatural. In "Meu Natal" (Dec. 21, 1968, 233-34), she describes a magical or mystical event that spared her prayer book after the night fire accident that consumed her bedroom: "houve o incêndio em meu quarto, incêndio que me atingiu tão gravemente que fiquei alguns dias entre a vida e a morte. Meu quarto foi inteiramente queimado: o estuque das paredes e do teto caiu, os móveis foram reduzidos a pó, e os livros também. Não tento sequer explicar o que aconteceu: tudo se queimou, mas o missal ficou intato, apenas com um leve chamuscado na capa" (234).

\section{Conclusion: A descoberta do mundo as a Journal of Resurrection}

Existentialism and phenomenology, or any reading of Sartre or Heidegger, would be empty theory had Lispector not borrowed from her own emotions and experiences as a Jewish girl in a Catholic milieu. Feeling Jewish coincided with her sense of rejection and seclusion, of being different, of pronouncing words awkwardly, and of being poor and motherless, in Recife ("Restos do Carnaval," 16 March, 1968, 105-08). "Banhos de mar" (January 25, 1969, 249) illustrates one of the few moments of relaxation, in contrast with "O passeio em família," which is written from an external point of view, as a subjective short story, but in the third person, and hints at the family's struggle with poverty (April 24, 1971, 533).

Lispector's increasing sense of abandonment and frustration led her to a condition of true melancholia, and craving for God became more and more 
constant and an ultimate goal for her. Her epiphanic discourse mingles mystical and existential insights and borders on mysticism. She counterbalances her sorrow with the sense of "Hased," and the hope for illuminated happiness. She mentions the word alegre 171 times in her chronicles, and she constantly urges people to be happy. Joy is mentioned in the Bible more than 3,000 times, and it is also a Hasidic perception of the omnipresence of the Divine. To be joyful or blissful often reads like a kind of mantra, as in "Ele seria alegre" (Dec. 21, 1968, 233). At the same time, this text exemplifies her peculiar way of treating religion in an existential perspective, as a desacralized human affair: "Cristo seria alegre se não precisasse mostrar ao mundo a dor do mundo: como homem era um ser perfeito e por isso teria alegrias perfeitas" (233). So often does she encourage people to be happy and blissful that this feeling seems a displacement from her own unhappiness, as in "A cozinheira feliz" (March 4, 1972, 643-44). Her letters from Europe often urge her older sister Elisa to be happy and jolly: "Minha irmã querida, minha Leinha, fique alegre, seja feliz!!!” (Rome, May 1, 1945, Minhas queridas, 21).

Lispector is neither happy nor funny in her chronicles. She seldom laughsshe is not comical, like Chekhov, although she is not deprived of a fine sense of humor. Nevertheless, she differs from the carioca spirit of the male chronicle writers of her time, or from the Modernist "poema piada," as in Oswald de Andrade. An exception is her chronicle published on All Fool's Day (April 1) of 1972, "Minha próxima e excitante viagem pelo mundo" (645-47, 645). Based on her actual travels in the past, she describes her fantastic plans to travel so precisely that she fools the reader almost up to the last line.

Another rare example of a funny literary chronicle, "Por causa de um bule de bico rachado" (Dec. 29, 1973, 765-67), narrates a long series of horrible personal incidents that an Englishman suffers after he has a prosaic discussion at breakfast with his wife about the cracked spout of a teapot. He flees home and joins the Foreign Legion for five years, sending no further news until a letter arrives stating that he is at great risk of death. So, his wife works extremely hard to save money to go find him to rescue him. The ending is left in suspense, adding to the absurd alacrity of this "chronicle."

"Amor, quati, cão, feminino e masculino" (Oct. 9, 1971, 598) is written in a witty tone from the viewpoint of this rodent, the coati, and illustrates Lispector's identification with animals. She depicts the sense of humiliation and 
awkwardness this wild animal feels by being paraded on a leash in the streets of Copacabana, as a pet. It makes one doubt Hélène Cixous's statement that women cannot laugh. This is no longer true. ${ }^{22}$

Some of these newspaper chronicles, written in the first person, reveal the psychological sorrows and the physical sufferings that Lispector went through during the six years she signed them, from 1967 to 1973, and extend back into her childhood. Like Franz Kafka, she was able to transform her loneliness, melancholy, and unhappiness into a social act. She helped many young women to become feminists. Her writings helped her contemporary women writers to affirm themselves on the same level as male authors (Lobo, "Clarice Lispector"). She wrote for her readers, but she also talked directly with God. She stressed the importance of being conscious and master of one's life.

Lispector's chronicles in A descoberta do mundo may be read as a literary journal that aims at gaining insight into women's conceptions of "self" and discovering the meaning of life. Marcel Proust's Remembrance of Things Past also resembles a journal that focuses on the author's life, nevertheless it does not emerge from the turmoil of social life, nor immerges in his inner self. While Proust is involved with this internal monologue, Lispector delves deeper into the imaginary and the sacred by means of stream of consciousness. Whereas Proust is realistic in his description of actions, scenes, characters and fashions, to draw a historical picture of his time, Lispector is mystical and abstract in what she sees. In order to achieve her mission as a writer, Lispector increasingly plunges into isolation to live like a Hasid. Only through suffering she seems to have found her own style and salvation.

Being so experimental in language and theme, Lispector is often compared to João Guimarães Rosa. While he used Taoism as his philosophical frame, she dug into existentialism, explored anti-metaphysics, and re-read religion to compose her original mystical texts. She employs a peculiar epiphany that derives from mystical and religious revelation, but which is also closely linked to everyday occurrences, where the divine makes frequent appearances.

\footnotetext{
22 "Para acabar de fundir a cuca" (August 12, 1972, 670) is a funny listing of folk beliefs that can be really amusing. However, in "Chacrinha?!" (October 7, 1967, 31), she criticizes this TV showman, who was often compared to a clown, stating that he deludes and exploits the audience by making fun of people who are in need of money. It looks as if she lacks sense of humor. "A bela e a fera ou a ferida grande demais" (1977) illustrates her constant worry and sadness.
} 
Her chronicles were often read as self-help texts, which became quite popular at the end of the millennium. However, they do not convey a ready-made message, neither do they aim only at selling or preaching; they are genuinely derived from her inner self. In line with an international trend of women's literature that began to emerge in the 1970s, Lispector was the first woman chronicler and fiction writer in Brazil to understand that women should write about their own world, their home, their worries, their self and their family, not to merely imitate male perceptions of the world.

\section{Works Cited}

Candido, Antonio. A crônica: o gênero, sua fixação e suas transformações no Brasil. U de Campinas, 1992.

Cixous, Hélène. Là. Gallimard, 1976.

Gaspari, Elio. As ilusões armadas. Companhia das Letras, 2002.

Montero Ferreira, Teresa Cristina. Eu sou uma pergunta. Rocco, 1999.

Gotlib, Nadia Batella. Clarice: uma vida que se conta. Ática, 1999.

Heidegger, Martin. Introduction to Metaphysics. Translated by Gregory Fried, Yale UP, 2000.

-. Off the Beaten Track. Translated by Julian Young and Kenneth Haynes, Cambridge UP, 2001.

Lispector, Clarice. "A bela e a fera ou a ferida grande demais." A paixão segundo G.H., edited by Benedito Nunes, U Federal de Santa Catarina and Unesco, 1988, pp. 151-57.

- A descoberta do mundo. Rocco, 1984.

-. A paixão segundo G.H., edited by Benedito Nunes, U Federal de Santa Catarina and Unesco, 1988.

-. A via-crucis do corpo. Rocco, 1974.

-. Minhas queridas. Rocco, 2007.

—. Todas as crônicas. Rocco, 2018.

Lispector, Elisa. No exílio. Gráfica Record, 1965.

Lobo, Luiza. "Clarice Lispector (1920-1977)." Guia de escritoras da literatura brasileira. U do Estado do Rio de Janeiro and Fundação de Amparo à Pesquisa do Estado do Rio de Janeiro, 2006, pp. 94-112. 
—. "Clarice Lispector e Virgínia Woolf." Crítica sem juízo, by Luiza Lobo, Garamond and Conselho Nacional de Desenvolvimento Científico e Tecnológico, 2007, pp. 34-50.

Manzo, Lícia. Era uma vez-eu: a não-ficção na obra de Clarice Lispector: ensaio. Governo de Estado do Paraná and Xerox do Brasil, 1998.

Moser, Benjamin. Why This World: A Biography of Clarice Lispector. Penguin, 2009.

Nunes, Benedito. O dorso do tigre. Perspectiva, 1976.

-. O mundo de Clarice Lispector. Governo do Estado do Amazonas, 1966.

Ribeiro, Victor Augusto Menezes. "Clarice Lispector nos limites da crônica literária." Crátilo, vol. 5, no. 2, 2012, pp. 121-31.

Sá, Jorge de. A crônica. Ática, 1985.

Sá, Olga de. A escritura de Clarice Lispector. Vozes, 1979.

Sant'Anna, Affonso Romano de; Colasanti, Marina. Com Clarice. U Estadual Paulista, 2013.

Sartre, Jean-Paul. Anti-Semite and Jew. Translated by George R. Becker, Schocken, 1948.

—. Being and Nothingness. Translated by Sarah Richmond, Routledge, 2018.

—. Existentialism is a Humanism. Translated by Carol Macomber, Yale UP, 2007.

—. Nausea. Translated by Lloyd Alexander, New Directions, 2013.

Simões, João Gaspar. "Clarice Lispector 'existencialista' ou 'suprarrealista." Diário Carioca. 28 May 1950.

Souza, Thais Torres de. As crônicas de Clarice Lispector. 2008. U de São Paulo, www.unicamp.br/iel/site/alunos/publicacoes/textos/c00012.htm.

Vieira, Nelson. "A expressão judaica na obra de Clarice Lispector." Remate de Males, vol. 9, 1989, pp. 207-09. 